\title{
Study of Growth Differentiation Factor 15(GDF15) and Some Biochemical Parameters in Multiple Myeloma Patients Subjected to Chemotherapy with Added Paroxetine in-Vitro
}

\author{
Zahraa A. H. Al-Timeeme ${ }^{1, *}$, Wisam Kadhum H. Alhashemi ${ }^{1}$, \\ Alaadin Sahham Naji ${ }^{2}$, Ahmed Fadhil Neama ${ }^{3}$ \\ ${ }^{1}$ Department of Chemistry, College of Science, Al-Nahrain University, Baghdad-Iraq \\ ${ }^{2}$ Baghdad Medical College, Baghdad, Iraq \\ ${ }^{3}$ Biotechnology Center, Al-Nahrain University, Baghdad, Iraq
}

\begin{tabular}{ll}
\hline \multicolumn{1}{c}{ Articles Information } & \multicolumn{1}{c}{ Abstract } \\
\hline Received: & Introduction: Multiple myeloma (MM) is a cancer that shapes from \\
24.04 .2020 & excessive amounts of a monoclonal immunoglobulin (Ig) which accumulate \\
Accepted: & in the bone marrow, where they assemble healthy blood cells. \\
28.05 .2020 & Materials and Methods: there are two lines was dealt with it: For in vivo the \\
Published: & study involved 80 multiple myeloma Patients grouped according sessions of \\
04.06 .2020 & chemotherapy (new diagnosis without treatment, and patients subjected to \\
& six sessions of chemotherapy treatment) for each group the following \\
& biochemical parameters were measured Growth differentiation factor 15 \\
& (GDF-15), albumin, calcium, C-reactive protein(CRP) in serum. In vitro was \\
Keywords: & measured Growth differentiation factor 15 on RPMI 8226 cell line of \\
Multiple myeloma (MM) & multiple myeloma with mixture of chemotherapy (Mix1) and with \\
Albumin & combination of standard chemotherapy and antideportation paroxetine \\
Serum Calcium & (Mix2). \\
C-reactive protein CRP & Results: In serum Growth differentiation factor 15 was showed significantly \\
Growth differentiation factor GDF-15 15 & increased (p<0.05) for 1st cycle and 6th Cycle in comparison with new \\
Bortezomib & diagnosis group, for other cycles there are no significant difference. For \\
Cyclophosphamide & Serum albumin, calcium and, C-reactive protein were appeared no \\
Paroxetine & significant between-groups differences when compared with their new \\
& diagnosis patients' group. In vitro Growth differentiation factor 15 was \\
& appeared significant different when compared results of cell line with Mix1 \\
\hline
\end{tabular}

DOI: $10.22401 /$ ANJS.23.2.03

*Corresponding author: zoza8462@gmail.com

\section{Introduction}

Multiple myeloma (MM) is a cancer of plasma cells, which malignant plasma cells collect in the bone marrow and produce lytic bone lesions and excessive quantities of a monoclonal immunoglobulin (Ig) [1, 2]. A one mass of myeloma cells is called a solitary plasmacytoma, which is overwhelmingly found in the bones but can also be found in soft tissue called an extramedullary plasmacytoma [3]. It's a cancer distinguish by plasma cells that reproduce very quickly and don't turn off when they should, this overgrowth inhibits the immune system and disrupts the continual process of bone remodeling[4, 5].Instead of creating antibodies that assist in fighting infection, myeloma cells develop essentially useless antibodies called "monoclonal" or "M" protein[6].
Multiple myeloma (MM) accounts for approximately $10 \%$ of hematologic malignant disorders $[7,8]$. The median age for this disease at 66-70) years with $37 \%$ of patients less than 65 years, and only $2 \%$ of patients are younger than 40 years of age at diagnosis $[9,10]$. The bone marrow (BM) of patients with MM contains malignant plasma cells, that output of cytokines, or activating BM cell secretion, which contribute to the unbalance between bone resorption and formation, resulting in the development of osteolytic lesions [11, 12]. Bortezomib (BTZ) is the first therapeutic proteasome inhibitor to be tested in humans[13]. BTZ is a boron containing molecule, which specifically and reversibly inhibits the threonine residue of the $26 \mathrm{~S}$ protease [14]. Despite the initial success of bortezomib therapy, multiple 


\title{
Al-Nahrain Journal of Science
}

\author{
ANJS, Vol.23 (2), June, 2020, pp. 18 - 25
}

myeloma remains incurable due in part to the emergence of bortezomib-resistant (BZR) cells rapidly develops in the majority of patients, so combination with cyclophosphamide reduced cell viability and the mixture is a well- endured regimen producing high overall and complete response rates, with little increase in toxicity compared to bortezomib alone[15]. Cyclophosphamide (CP) is a cancer medication used as chemotherapy that interferes with the growth and spread of cancer cells in the body. As chemotherapy it is used to treat lymphoma, multiple myeloma, leukemia, ovarian cancer, breast cancer, small cell lung cancer, neuroblastoma, and sarcoma. It is taken by mouth or injection into a vein. $\mathrm{CP}$ a prodrug that is enzymatically converted to the cytotoxic 4hydroxycyclophosphamide (4OHCP) by hepatic enzymes [16]. Paroxetine is an antidepressant of the selective serotonin reuptake inhibitor (SSRI) class [17]. Paroxetine is a mechanism-based inhibitor of Cytochrome P450 2D6 (CYP2D6) [18]. Paroxetine play important role as efflux pump inhibitor for cancers by take role as $\mathrm{P}$-glycoprotein inhibitors are competitive substrates for $\mathrm{P}$ glycoproteins, as shown in research, PO Ughachukwu, et al., [19]. There are many biochemical parameter which can reflect the effect of standard chemotherapy of cancer on body for multiple myeloma, Growth differentiation factor 15 (GDF-15) is a protein member of the transforming growth factor $B$ (TGF- B) cytokine superfamily [20]. It is produced in low amounts under baseline conditions in most tissues such as brain, liver, kidney, pancreas, but not normally in many other organs including the heart. It is high level in placenta and moderately in prostate [21]. Because GDF15 protein concentration can be easily determined in the circulation, many studies have identified it as an important plasma biomarker that relate with several diseases [22-28]. Human albumin (HA) is the most plentiful circulating protein in the plasma of healthy individuals, since it reflects about $50 \%$ of the total protein content [29]. Serum albumin reflects the interleukin-6 (IL6) levels which is inversely proportional with it, and reflects IL-6 effects on the liver [30]. Albumin reflects the severity of MM disease [31], albumin concentration decreases notably in patients' serum $<3.5 \mathrm{~g} / \mathrm{dL}$. Calcium is the most bountiful mineral element in the body. About $98 \%$ of calcium in the adult is in the shape of hydroxyapatite in the skeleton [32]. Identified serum calcium as an important plasma biomarker for the multiple myeloma [33]. Calcium concentration increase notably in patients' serum $>11 \mathrm{mg} / \mathrm{dl}[34]$. Creactive protein $(\mathrm{CRP})$ is protein structure and are dependent on calcium for ligand binding, found in blood plasma[35], and is a polypeptide secreted by hepatocytes in response to IL-6; hence, it can be used as a surrogate marker for IL- 6 in the serum $[36,37]$. CRP an important plasma biomarker for the multiple myeloma [37], which it concentration elevates notably in patients' serum > upper normal limit (8 mg/L) [38].

\section{Materials and Methods}

Eighty multiple myeloma cancer patients were investigated with their ages in the range $32-85$ years of both males (37) and females (43). Bloods were collected from the patients attended Baghdad Teaching Hospital, Medical city, in Baghdad, Iraq. The patients were chosen according to cycles of chemotherapy that were taken. During the period from November 2018 to April 2019. About $5 \mathrm{ml}$ of blood sample was drawn from each patient. Collect whole blood in a covered a gel tube, allowed to clot at room temperature for 20 minutes; the clot was removed by centrifuging at 3500 (r.p.m) for 10 minutes. Serum for each sample divided to several parts and transferred to clean Eppendorf tubes using micropipette and all tubes stored at -30C until the time of analyzed [39]. The parameters and techniques used in this study were; Serum Growth differentiation factor 15 (GDF-15) ( Kit provided by SHANGHAI YEHUA Biological Technology)/ enzyme-linked immune sorbent assay (ELISA) are used in this analysis, Serum Creactive protein (CRP) (Kit provided by Bio Systems S.A -Barcelona /Spain ) latex agglutination are used in this analysis, Serum Calcium ( Kit provided by Bio Systems S.A Barcelona /Spain )/ spectrophotometer technique are used in this analysis, Serum Albumin ( Kit provided by Bio Systems S.A -Barcelona /Spain )/ spectrophotometer technique are used in this analysis.

The Statistical Analysis System- SAS (2012) program was used to detect the effect of difference factors in study parameters. Least significant difference -LSD test (Analysis of VariationANOVA) was used to significant compare between means. Estimate of Correlation coefficient between parameters in this study. The figures were done by used Microsoft Excel program in vivo and in vitro. In vivo difference considers significantly at * $(\mathrm{P}<0.05)$, but for in vitro at $(* * \mathrm{p} \leq 0.01)$ and $(* \mathrm{p} \leq$ $0.05)[40]$. 


\section{Al-Nahrain Journal of Science}

ANJS, Vol.23 (2), June, 2020, pp. 18 - 25

\section{Results and Discussion}

First lines: we worked on four biochemical parameters in vivo. The result of GDF15 protein level in serum samples of MM patient's groups which were divided into groups according to number cycles of chemotherapy are shown in the Table 1 and Figure 1.

Table 1. Serum GDF15 concentration (ng/L) in MM patients, compared between patient's groups (new diagnosis and patients took cycles of chemotherapy).

\begin{tabular}{lll}
\hline Cycle & No & Mean \pm SE of GDF-15 \\
\hline New diagnosis & 6 & $393.85 \pm 226.55 \mathrm{~b} \mathrm{c}$ \\
Cycle $1^{\text {st }}$ & 9 & $692.33 \pm 383.32 \mathrm{a}$ \\
Cycle 2 & 9 & $173.83 \pm 16.86 \mathrm{c}$ \\
Cycle $3^{\text {rd }}$ & 8 & $539.97 \pm 308.37 \mathrm{ab}$ \\
Cycle $4^{\text {th }}$ & 16 & $425.06 \pm 168.72 \mathrm{ab}$ \\
Cycle 5 & 8 & $149.92 \pm 6.96 \mathrm{c}$ \\
Cycle 6 (or more) & 24 & $602.70 \pm 202.60 \mathrm{a}$ \\
LSD value & --- & $289.73^{*}$ \\
P-value & --- & 0.0377 \\
\hline
\end{tabular}

a, b, c, Different letters: significant * $(\mathrm{P}<0.05)$ between the means of column.

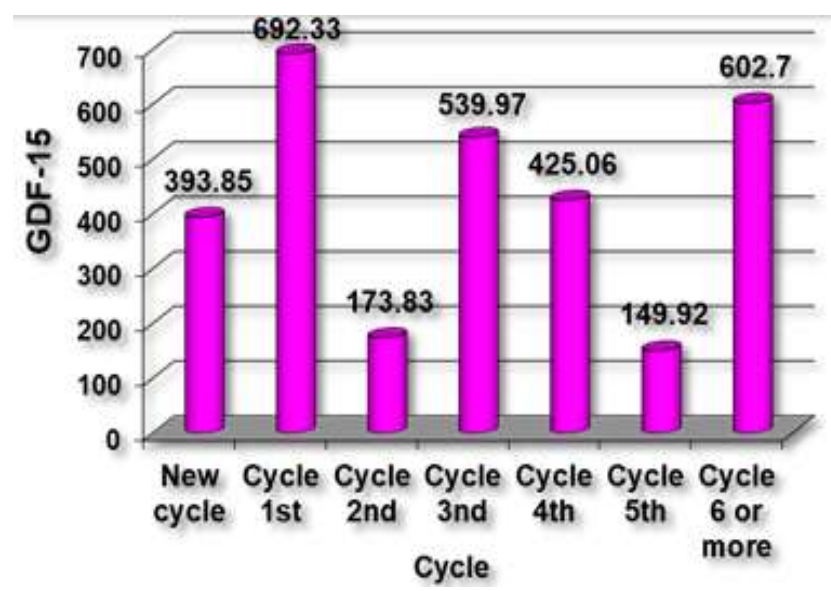

Figure 1. Serum GDF15 concentration (ng/L) in MM patients

The mean level GDF15 in MM patients for cycle 1 st $(692.33 \pm 383.32)$ and Cycle 6th $(602.70 \pm$ 202.60) were showed significantly increased $(\mathrm{p}<0.05)$ in comparison with new diagnosis group $(393.85 \pm 226.55)$ as shown Table (1.1), GDF15 is produced in low amounts under baseline conditions in most tissues [21], Overexpression of GDF15 by bone marrow mesenchyme stem cells occurs widely in patients with MM [23, 24, 41]. For first cycle may be due to taking the combinations of chemotherapy drugs by patients, which effects on the most cells of body infected and healthy cells that led to kill some of these cells and secretion of its components in the blood circulation, which made to a high rate in this components and including GDF15. As for 6th cycle concentration increasing, may be result of malignance cells of MM resistance to chemotherapy, which made the cells secreted high level of GDF15, or may be because small samples size. That possibly explains the reason of rise level of GDF15 in these two groups of samples. For cycle 2nd $(173.83 \pm 16.86)$, cycle 3rd $(539.97 \pm 308.37)$, cycle 4 th $(425.06 \pm$ $168.72)$ and cycle 5 th $(149.92 \pm 6.96)$ there are no significant difference, which maybe refer to response patients to chemotherapy, or there no response at all and the tumor state as is begin.

When compared the mean of albumin of group's patients (from 1st cycle to 6th cycle) with group (new diagnosis) of patients, was noted nonsignificant, as shown in table 2 and figure 2.

Table 2. Serum albumin concentration $(\mathrm{g} / \mathrm{dl})$ in MM patients, compared between patient's groups (new diagnosis and patients took cycles of chemotherapy).

\begin{tabular}{lll}
\hline Cycle & No & $\begin{array}{l}\text { Mean } \pm \text { SE of Albumin } \\
(\mathrm{g} / \mathrm{dl})\end{array}$ \\
\hline $\begin{array}{l}\text { New Diagnosis } \\
\text { Patients ab }\end{array}$ & 6 & $5.15 \pm 0.70$ \\
Cycle 1st & 9 & $4.90 \pm 0.46 \mathrm{ab}$ \\
Cycle 2nd & 9 & $4.87 \pm 0.18 \mathrm{ab}$ \\
Cycle 3rd & 8 & $4.43 \pm 0.59 \mathrm{~b}$ \\
Cycle 4th & 16 & $5.01 \pm 0.32 \mathrm{ab}$ \\
Cycle 5th & 8 & $4.21 \pm 0.37 \mathrm{ab}$ \\
Cycle 6 or more & 24 & $5.68 \pm 0.21 \mathrm{a}$ \\
LSD value & --- & $1.194 *$ \\
P-value & --- & 0.0459 \\
\hline
\end{tabular}

$a, b$, Different letters: significant $*(P<0.05)$ between the means of column. 


\section{Al-Nahrain Journal of Science}

ANJS, Vol.23 (2), June, 2020, pp. 18 - 25

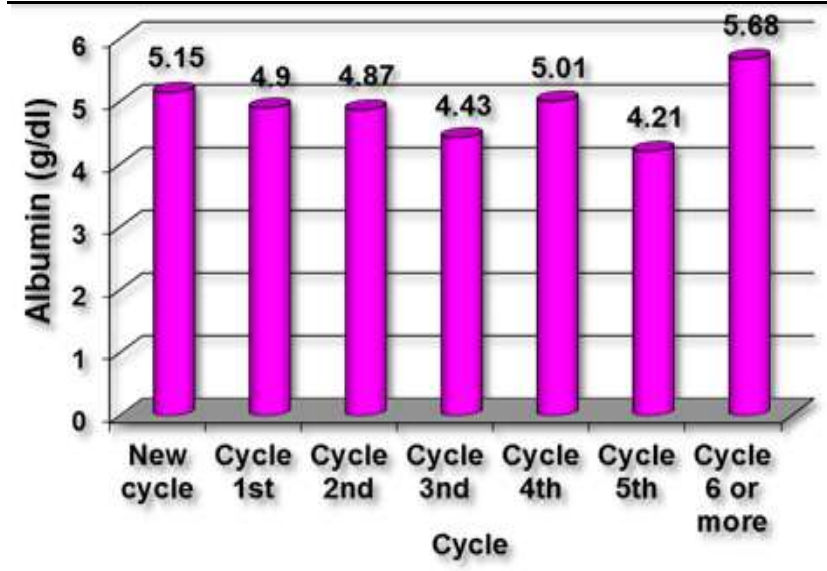

Figure 2. Serum albumin concentration $(\mathrm{g} / \mathrm{dl})$ in MM patients.

Although the Mean of cycle new diagnosis (6 patients) appear within the normal range of albumin which contrasts with the reality of the patients of MM, who suffers from abnormal results of albumin before undergoing to treatment sessions, but when detailing the results collected from patients observed the level of albumin for (2) patients of them was lower than $3.5(\mathrm{~g} / \mathrm{dl})$, hypoalbuminemia reflected the severity of MM, decreased levels of albumin may result from decreased synthesis. Serum albumin reflects the interleukin-6 levels, the liver function and the nutritional status [30, 42]. These results of lower serum albumin in patients of MM correspond with a number of studies [33, 43, and 44]. For the rest of (4) patients were showed a significant increase more than $5.5(\mathrm{~g} / \mathrm{dl})$, which Increase in serum albumin concentration may be attributed to protect against early glycemic deterioration and progression to type 2 diabetes [205], high percentage of patient s' MM have diabetes, whose appearance coincided with the disease, this information was took from patients' records in hospital. In the rest of groups, too, was observed an elevation in serum albumin for some patients, despite of receiving the chemotherapy, that may be because acute dehydration [45], because diarrhea is one of the main drawbacks for cancer patients which accompanies most cancer patients receiving chemotherapy [46].

The 'Mean' gradually decreased to reached the lowest stage in third session of chemotherapy (3rd cycle) $(4.43 \pm 0.59 \mathrm{~g} / \mathrm{dl})$ compared with new diagnosis $(5.15 \pm 0.70 \mathrm{~g} / \mathrm{dl})$, and then rose again in (cycle 4 th) $(5.01 \pm 0.32 \mathrm{~g} / \mathrm{dl})$ and (6th cycle $)(5.68 \pm$ $0.21 \mathrm{~g} / \mathrm{dl}$ ), may be refer to success of treatment to this session and then raised the resistance to treatment in the following sessions or simply this happen because the small sample size taken from patients in this sessions.

Can be notes the mean level of cycles 1 st, cycle2nd, and cycle6th) higher than range of calcium in blood $(8.5-10.5) \mathrm{mg} / \mathrm{dl}$ [47], for the rest of cycles (cycle $3 \mathrm{rd}$, cycle 4th, and cycle 5th) at the maximum value of the level. The mean level of serum calcium in MM patients for cycle 1ST (11.67 \pm 1.02$)$, cycle 2nd $(11.28 \pm 0.42)$, cycle $3 r d(10.68 \pm 1.35)$, cycle 4 th $(9.79 \pm 1.14)$, cycle 5 th $(10.52 \pm 1.88)$ and cycle 6 th or more $(13.21 \pm 0.93)$ when comparison with new diagnosis patients $(11.94 \pm 1.75)$ there are non-significant as shown in table 3 and figure 3 , this results probably reflects the success of chemotherapy by prevent the deterioration of the patient's condition, or possibly because small samples size. Except when compare cycle 6th $(13.21 \pm 0.93)$ with cycle 4 th $(9.79 \pm 1.14)$ calcium show high significant increase with $\mathrm{P}<0.05$, Perhaps in cycle 4 th session of treatment the best response is achieved.

Table 3. Serum calcium concentration $(\mathrm{mg} / \mathrm{dl})$ in MM patients, compared between patient's groups (new diagnosis and patients took cycles of chemotherapy).

\begin{tabular}{lcl}
\hline Cycle & No & $\begin{array}{l}\text { Mean } \pm \text { SE of Ca } \\
(\mathrm{mg} / \mathrm{dl})\end{array}$ \\
\hline New cycle & 6 & $11.94 \pm 1.75 \mathrm{ab}$ \\
Cycle 1st & 9 & $11.67 \pm 1.02 \mathrm{ab}$ \\
Cycle 2nd & 9 & $11.28 \pm 0.42 \mathrm{ab}$ \\
Cycle 3rd & 8 & $10.68 \pm 1.35 \mathrm{ab}$ \\
Cycle 4th & 16 & $9.79 \pm 1.14 \mathrm{~b}$ \\
Cycle 5th & 8 & $10.52 \pm 1.88 \mathrm{ab}$ \\
Cycle 6 or more & 24 & $13.21 \pm 0.93 \mathrm{a}$ \\
LSD value & --- & $3.013^{*}$ \\
P-value & --- & 0.04264 \\
\hline
\end{tabular}

$\mathrm{a}, \mathrm{b}$, Different letters: significant * $(\mathrm{P}<0.05)$ between the means of column. 


\section{Al-Nahrain Journal of Science}

ANJS, Vol.23 (2), June, 2020, pp. 18 - 25

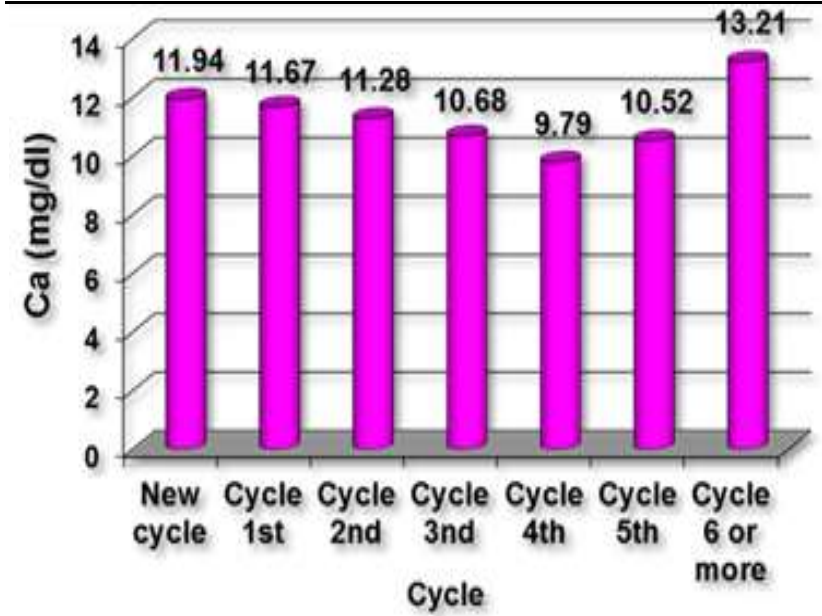

Figure 3. Serum calcium concentration $(\mathrm{g} / \mathrm{dl})$ in MM patients.

It is observed that results of four of groups (new dignosis, 1thcycle, 2nd cycle, and 6th cycle or more), it indicates a height in concentration of calcium above the reference values, which can account for this disease is associated with excessive tumor-induced, osteoclast-mediated bone destruction, which causes of hypercalcemia is widespread by tumor-induced bone destruction [48], These results of higher serum calcium in patients of MM correspond with a number of studies [48-50].

Table 4. C - reactive protein concentration $(\mathrm{mg} / \mathrm{l})$ in MM patients, compared between patient's groups (new diagnosis and patients took cycles of chemotherapy).

\begin{tabular}{lll}
\hline Cycle & No & Mean \pm SE of CRP $(\mathrm{mg} / \mathrm{l})$ \\
\hline New cycle & 6 & $13.33 \pm 4.46 \mathrm{ab}$ \\
${\text { Cycle } 1^{\text {st }}}_{\text {Cycle 2 }^{\text {nd }}}$ & 9 & $13.33 \pm 1.98 \mathrm{ab}$ \\
Cycle 3 $^{\text {rd }}$ & 9 & $10.67 \pm 1.88 \mathrm{~b}$ \\
Cycle $^{\text {th }}$ & 16 & $17.00 \pm 3.52 \mathrm{a}$ \\
Cycle 5 $^{\text {th }}$ & 9 & $17.60 \pm 1.78 \mathrm{ab}$ \\
Cycle 6 or more & 24 & $11.67 \pm 1.70 \mathrm{a}$ \\
LSD value & --- & $6.198 *$ \\
P-value & --- & 0.04923
\end{tabular}

a,b, different letters: significant * $(\mathrm{P}<0.05)$ between the means of column.

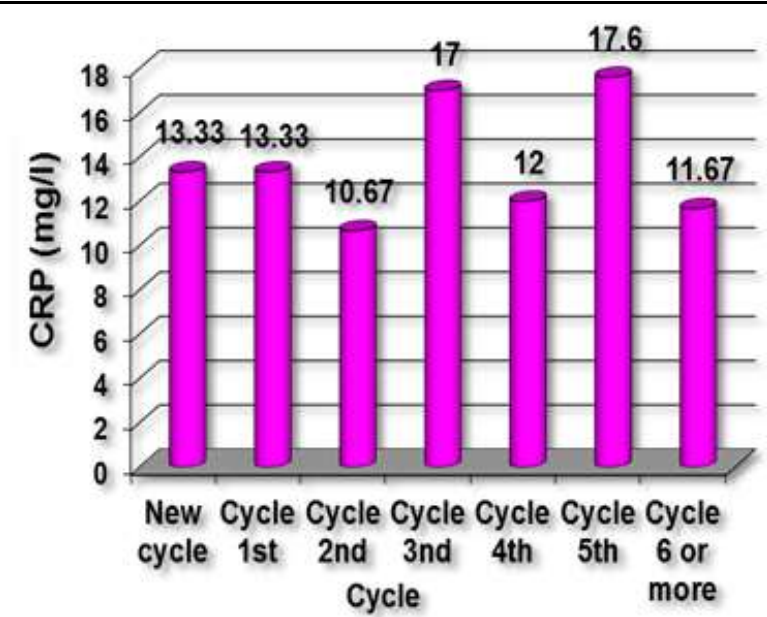

Figure 4. C-Reactive Protein concentration $(\mathrm{g} / \mathrm{dl})$ in MM patients.

The mean level of serum CRP in MM patients for cycle 1 st $(13.33 \pm 1.98)$, cycle 2 nd $(10.67 \pm 1.88)$, cycle 3rd $(17.00 \pm 3.52)$, cycle 4 th $(12.00 \pm 1.78)$, cycle 5th $(17.60 \pm 6.40)$ and cycle 6 th or more $(11.67 \pm 1.73)$ there are no significant difference when comparison with new diagnosis patients $(13.33 \pm 4.46)$ as shown table (3.3), while there is high significant $(\mathrm{P}<0.05)$ when compare cycle 2nd with cycle $3 \mathrm{rd}$ and cycle 5th. All groups are showed height from CRP normal range $(0.8-3.0 \mathrm{mg} / \mathrm{L})$, which might be serve as an indicator of infection and inflammation, Interleukin-1B (IL- 1B) and tumor necrosis factor- $\alpha$ (TNF- $\alpha$ ), both cytokines for MM, also lead to increased production of CRP [51]. CRP is a polypeptide secreted by hepatocytes in response to IL-6; hence, it can be used as a surrogate marker for IL-6 in the serum [52]. These results of height serum CRP in patients of MM correspond with a number of studies [36, 38, 53].

Second lines: Was defined the effect of drugs mixture Mix1(Bortezomib10\% and Cyclophosphamide 90\%) \& Mix2 (Bortezomib plus Cyclophosphamide 50\% with paroxetine 50\%) on GDF15 production by RPMI-8226 cells, the cells were first treated with different concentrations of both combinations (1000, 500, 250 and $125 \mu \mathrm{M})$.as could see in Table (5). We could see the effect of mix 1from $125 \mu \mathrm{M}(68.71 \%)$ to $1000 \mu \mathrm{M}(51.14 \%)$ on secretion of GDF15 from cells line of MM, were appeared marked decrease in concentration of the secreted parameter, and corresponds to increasing the concentration of Mix1. Were noted the same effect by Mix2 from $125 \mu \mathrm{M}(38.21 \%)$ to $1000 \mu \mathrm{M}$ (33.29\%), which reduced the secreted GDF15 by increasing the concentration of Mix2, as shown in figure 5. By measuring protein GDF15 


\section{Al-Nahrain Journal of Science}

ANJS, Vol.23 (2), June, 2020, pp. 18 - 25

concentrations in vivo and vitro, that can give us an idea of the effect of treatment Mix1 and Mix2 and which one of them more effect. GDF15 concentration remained constant in vivo, whereas the change was significantly in vitro when confronted the effect of Mix1 and Mix2 on level of
GDF15 in cell line. This is evident in figure 6. We can conclude that paroxetine achieves promising results by enhancing the effect of chemotherapy on multiple myeloma cancer.

Table 5. effect of Mix1 \& Mix2 on GDF15 and compared the results between each other.

\begin{tabular}{|c|r|r|r|r|r|}
\hline \multirow{2}{*}{ Conc. $\boldsymbol{\mu M}$} & \multicolumn{2}{|c|}{ GDF 15 at Mix1 } & \multicolumn{2}{|c|}{ GDF15 at Mix2 } & \multirow{2}{*}{ P value (compared between Mix1\&Mix2) } \\
\cline { 2 - 5 } & Mean & SE & Mean & SE & \\
\hline $\mathbf{1 2 5}$ & 68.71 & 11.247 & 38.21 & 10.310 & $* * \mathrm{p} \leq 0.01$ \\
\hline $\mathbf{2 5 0}$ & 58.44 & 3.280 & 37.69 & 8.435 & $* * \mathrm{p} \leq 0.01$ \\
\hline $\mathbf{5 0 0}$ & 58.44 & 8.904 & 35.66 & 0.483 & $* * \mathrm{p} \leq 0.01$ \\
\hline $\mathbf{1 0 0 0}$ & 51.14 & 2.343 & 33.29 & 0.937 & $* \mathrm{p} \leq 0.05$ \\
\hline
\end{tabular}

For GDF15 in untreated cell was undetected, may be due to concentrations of GDF15 under detection limits.

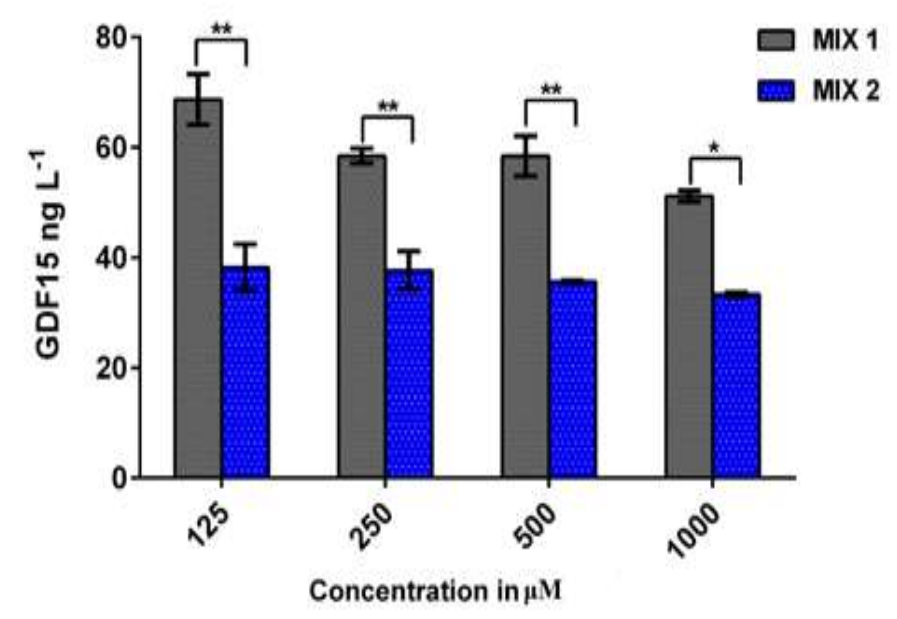

Figure 5. Effect of Mix1 \& Mix2 on GDF15 and compared the results between each other.

\section{Conclusions}

In conclusion the biochemical parameters concentration measured in vivo in this study including (GDF15) didn't affected by scissions of chemotherapy. The results led us to recommended either to use larger sample size or use more sensitive biochemical parameter to observe the change made it by these treatments or simply the effect is just deterring disease to be worsen especially all these parameters are in it reference value. For other biochemical parameters, height level calcium indicates to the severity of disease by reflect the tumor-induced bone destruction in patients. CRP which might be serve as an indicator of infection and inflammation in patients of MM. In this study albumin level refers that chemotherapy led to its stability and maintaining the disease does not deteriorate. In other hand in vitro study, added paroxetine to chemotherapy Mix 1(BTZ and CP) in cell line of MM, lead to significantly change in proportions of survivals compared with Mix1 alone. These results are promising for use as paroxetine to enhancing chemotherapy effects in remedy the disease.

\section{Acknowledgement}

The authors would like to acknowledge patients, Baghdad Teaching Hospital, Medical city and Department of chemistry, College of science, AlNahrain University, for the support to do this project.

\section{References}

[1] Konrad, C. N.; William, D. L.; "Multiple myeloma: diagnosis and treatment"; Am. Fam. Physician, 78, 853-859, 2008

[2] Hargreaves, R. M.; Lea, J. R.; Griffiths, H.; Faux, J. A.; Holt, J. M.; Reid, C.; Bunch, C.; Lee, M.; Chapel, H. M.; "Immunological factors and risk of infection in plateau phase myeloma"; Am. J. Clin. Pathol., 48, 260-266, 1995.

[3] Nissim, O.; Ory, R.; Karen, N.; Dimitri, S.; Daniel, B.; "Classification of Solitary Plasmacytoma, is it more Intricate than Presently Suggested? A Commentary"; J.Cancer, 9, 3894, 2018.

[4] Roberto, J. P. M.; María-Belén, V.; Bruno, P.; Carlos, F.; Ramón, G.; Maria-Victoria, M.; Norma, C. G.; Quentin, L.; Juan, F. B.; Jose, H.; "Analysis of the immune system of multiple myeloma patients achieving long-term disease control by multidimensional flow cytometry"; Haematologica, 98, 79-86, 2013.

[5] Michaela, R. R.; Lucy, L.; Clifford, J. R.; Irene, M.G.; "Dynamic interplay between bone and 


\title{
Al-Nahrain Journal of Science
}

\author{
ANJS, Vol.23 (2), June, 2020, pp. 18 - 25
}

multiple myeloma: emerging roles of the osteoblast"; Bone, 75,161-169, 2015.

[6] Al-Farsi, K.; "Multiple myeloma: an update"; Oman Med. J., 28, 3, 2013.

[7] Nikolaus, B.; "Epidemiology of multiple myeloma"; Springer, 25-35; 2011.

[8] Rajkumar, S. V.; "Multiple myeloma: 2016 update on diagnosis, risk-stratification, and management"; Am. J. Hematol., 91, 719-734, 2016.

[9] Dickran, K.; "Multiple myeloma epidemiology and survival: A unique malignancy"; SEMIN ONCOL, Elsevier,. 43, 676-681, 2016.

[10] Robert, A. K.; Morie, A. G.; Thomas, E. T.; John, A. L.; Martha, Q. L.; Angela, D.; Rafael, F.; "Review of 1027 patients with newly diagnosed multiple myeloma"; Mayo Clin. Proc., Elsevier, 78, 21-33, 2003.

[11] Regis, B.; Daniel, C.; Christian, M.; Philippe, M.; Jacques, S.; Pierre, B.; Christian, A.; "Mechanisms of bone destruction in multiple myeloma: the importance of an unbalanced process in determining the severity of lytic bone disease"; J. Clin. Oncol., 7, 1909-1914, 1989.

[12] Oranger, A.; Carbone, C.; Izzo, M.; Grano, M.; "Cellular mechanisms of multiple myeloma bone disease"; Clin. Dev. Immunol., 2013, 2013.

[13] Chen, D.; Frezza, M.; Schmitt, S.; Kanwar, J.; Dou, Q. P.; "Bortezomib as the first proteasome inhibitor anticancer drug: current status and future perspectives"; Curr. Cancer Drug Targets, 11, 239$253,2011$.

[14] Masaki, R.; "Mechanism of action of bortezomib in multiple myeloma therapy"; Inte. J. Myeloma, 6, 16, 2016.

[15] Davies, F. E.; Wu, P.; Jenner, M.; Srikanth, M.; Saso, R.; Morgan, G. J.; "The combination of cyclophosphamide, velcade and dexamethasone (CVD) induces high response rates with comparable toxicity to velcade alone (V) and velcade plus dexamethasone (VD) "; Haematologica, 92, 11491150, 2007.

[16] Ramirez, D. A.; Collins, K. P.; Aradi, A. E.; Conger, K. A.; Gustafson, D. L; "Kinetics of Cyclophosphamide Metabolism in Humans, Dogs, Cats, and Mice and Relationship to Cytotoxic Activity and Pharmacokinetics"; Drug Metab. Dispos. 47, 257-268, 2019.

[17] Marianna, P.; Davide, P.; Chiara, G.; Carlotta, T.; Laura, R. M.; Carla, R.; Toshi, A. F.; Norio, W.; Andrea, C.; Corrado, B.; "Paroxetine versus other anti-depressive agents for depression"; Cochrane Database Syst. Rev., 2014.

[18] Caraci, F.; Crupi, R.; Drago, F.; Spina, E.; "Metabolic drug interactions between antidepressants and anticancer drugs: focus on selective serotonin reuptake inhibitors and hypericum extract"; Curr. Drug Metab., 12, 570577, 2011.

[19] Ughachukwu, P.; Unekwe, P.; "Efflux Pump. Mediated Resistance in Chemotherapy"; Ann. Med. Health Sci. Res., 2, 191-198, 2012.
[20] Derya, A.; Tugba, C.; Dogan, K.; Husamettin, V.; Derya, C.; Yavuz, K.; Bulent, O.; Fikret, A.; "Growth-differentiation factor-15 and tissue doppler imaging in detection of asymptomatic anthracycline cardiomyopathy in childhood cancer survivors"; Clin. Biochem., 46, 1239-1243, 2013.

[21] Lung-An, H.; Semon, W.; Jyh-Ming, J. J.; Fu-Tien, J.; Ming-Sheng, T.; Jeng-Feng, J.; Hsuan-Li, H.; Yu-Lin, K.; "Growth differentiation factor 15 may predict mortality of peripheral and coronary artery diseases and correlate with their risk factors"; Mediat. Inflamm., 2017, 2017.

[22] Ting, W.; Jian, L.; Caitlin, M.; Katherine, L.; Xiandun, Z.; Benjamin, J. W.; Hakon, H.; Liming, P.; "GDF15 is a heart-derived hormone that regulates body growth"; EMBO mol. Med., 9, 11501164, 2017.

[23] Jill, C.; Elodie, L.; Nicolas, E.; Benjamin, H.; AvetLoiseau, H.; Murielle, R.; Anne, H.; Mélanie, A.; Pierre, C.; Bernard, K.; "Bioactivity and prognostic significance of growth differentiation factor GDF15 secreted by bone marrow mesenchymal stem cells in multiple myeloma"; Cancer Res., 72, 1395-1406, 2012.

[24] Efstathios, K.; Giampaolo, M.; Ioannis, P.; Paolo, M.; Evangelos, T.; Marco, B.; Athanasios, A.; Francesca, R.; Erasmia, P.; Filia, P.; "Growth Differentiation Factor-15 (GDF-15) Is a new biomarker with independent prognostic significance for survival and renal outcomes in different cohorts of patients with light chain (AL) Amyloidosis"; ASH., DC, 128, 2016.

[25] Efstathios, K.; Giampaolo, M.; Ioannis, P.; Paolo, M.; Evangelos, T.; Marco, B.; Athanasios, A.; Francesca, R.; Erasmia, P.; Filia, P.; "Growth differentiation factor-15 is a new biomarker for survival and renal outcomes in light chain amyloidosis"; blood, 131, 1568-1575, 2018.

[26] Shiu Lun Au, Y.; Shan, L.; Mary, C. S.;"The impact of GDF-15, a biomarker for metformin, on the risk of coronary artery disease, breast and colorectal cancer, and type 2 diabetes and metabolic traits: a Mendelian randomisation study"; Diabetologia, 1-9, 2019.

[27] Adela, R.; Banerjee, S. K.; "GDF-15 as a target and biomarker for diabetes and cardiovascular diseases: a translational prospective"; J. Diabetes Res., 2015, 2015.

[28] Toshihiko, T.; Yiting, L.; Qiuju, W.; Marta, C.; Leif, B. P.; Geoff, M.; Ricky, W. J.; Nilanjan, G.;"Growth differentiating factor 15 enhances the tumorinitiating and self-renewal potential of multiple myeloma cells"; Blood, 123, 725-733, 2014.

[29] Caraceni, P.; Tufoni, M.; Bonavita, M. E.; "Clinical use of albumin"; Blood, 11, 18, 2013.

[30] Kim, J. E.; Yoo, C.; Lee, D. H.; Kim, S.-W.; Lee, J.S.; Suh, S.; "Serum albumin level is a significant prognostic factor reflecting disease severity in symptomatic multiple myeloma"; Ann. Hemat., 89, 391-397, 2010. 


\section{Al-Nahrain Journal of Science}

ANJS, Vol.23 (2), June, 2020, pp. 18 - 25

[31] Rami, S. K.; Corrales-Yepez, M.; Kharfan-Dabaja, M. A.; Al Ali, N. H.; Eric, P.; Dana, E. R.; PinillaIbarz, J.; Ling, Z; Epling-Burnette, P. K.;

[32] Jeffrey. E. L.; "Hypoalbuminemia is an independent prognostic factor for overall survival in myelodysplastic syndromes"; Am. J. Hematol., 87, 1006-1009, 2012.

[33] Astrid, S.; Helmut, S.; Roland-KO, S.; "Interrelations between essential metal ions and human diseases"; Springer, 13; 2013.

[34] Nepal, A.K.; Shakya, P. R.; Gelal, B.; Das, B. L.; Shrestha, B. P.; Lamsal, M.; Baral, N.; Majhi, S.; "Biochemical profile of Multiple Myeloma in the patients visiting bpkihs as diagnosed by agarose gel electrophoresis"; Health Renaiss., 8, 122-125, 2010.

[35] Ashrafi, F.; Iraj, B.; Nematollahi, P.; Darakhshandeh, A.; "Pseudohypercalcemia in multiple myeloma: A case report"; Int. J. Hematol. Oncol. Stem Cell Res., 11, 246, 2017.

[36] Chandrashekara, S.; "C-reactive protein: An inflammatory marker with specific role in physiology, pathology, and diagnosis"; Int. J. RCI., $2,2014$.

[37] Jing, Y.; Zhiqiang, L.; Huan, L.; Jin, H.; Jianling, Y.; Pei, L.; Qiang, W.; Juan, D.; Wencai, M.; Zheng, Y.;"C-reactive protein promotes bone destruction in human myeloma through the CD32-p38 MAPKTwist axis"; Sci. Signal., 10, 6282, 2017.

[38] Bataille, R.; Boccadoro, M.; Klein, B.; Durie, B.; Pileri, A.; "C-reactive protein and beta-2 microglobulin produce a simple and powerful myeloma staging system"; Am. J. Hematol., 80, 733-737, 1992.

[39] Chakraborty, R.; Muchtar, E.; Kumar, S. K.; Buadi, F. K.; Dingli, D.; Dispenzieri, A.; Hayman, S.R.; Hogan, W.J.; Kapoor, P.; Lacy, M. Q.; "Elevated pre-transplant C-reactive protein identifies a highrisk subgroup in multiple myeloma patients undergoing delayed autologous stem cell transplantation"; Bone Marrow Transplant., 53, 155-161, 2018.

[40] Tammen, H.; Hess, R.; "Collection and handling of blood specimens for peptidomics"; Springer, 161168, 2013.

[41] Cary, N.; "Statistical Analysis System, User's Guide. Statistical. Version 9.SAS. Inst"; Inc. USA, 2012.

[42] Toshihiko, T.; Yiting, L.; Qiuju, W.; Marta, C.; Leif, B. P.; Geoff, M.; Ricky, W. J.; Nilanjan, G.; Ivan, B.; Carol, A. H.; "Growth differentiating factor 15 enhances the tumor-initiating and self-renewal potential of multiple myeloma cells"; Am. J. Hematol., Blood, 123, 725-733, 2014.

[43] Akirov, A.; Masri-Iraqi, H.; Atamna, A.; Shimon, I.; "Low albumin levels are associated with mortality risk in hospitalized patients"; Am. J. Med., 130, 1465. e11-1465. e19, 2017.

[44] Ma, T. Z.; Piao, Z.; Jin, S. Y.; Kwak, Y. G.; "Differential expression of serum proteins in multiple myeloma"; Exp. Ther. Med., 17, 649-656, 2019 .
[45] Jia-Hong, C.; Shun-Neng, H.; Tzu-Chuan, H.; YiYing, W.; Chin, L.; Ping-Ying, C.; Yeu-Chin, C.; Ching-Liang, H.; "Prognostic significance of initial serum albumin and 24-hour daily protein excretion before treatment in multiple myeloma"; PloS one, $10,2015$.

[46] Busher, J. T.; "Serum albumin and globulin"; Clinical methods: The history, physical, and laboratory examinations, 3,1990 .

[47] Stein, A.; Voigt, W.; Jordan, K.; "Chemotherapy" induced diarrhea: pathophysiology, frequency and guideline-based management"; Ther. Adv. Med. Oncol., 2, 51-63, 2010.

[48] Pravina, P.; Sayaji, D.; Avinash, M.; "Calcium and its role in human body"; Int. J. Res. Pharm. Biomed. Sci, 4, 659-668, 2013.

[49] Oyajobi, B. O.; "Multiple myeloma/hypercalcemia," Arthritis Res. Ther., 9, S4, 2007.

[50] Mateu, J. M.; González, G. L.; Vila, M.; Rivera, M. U.; Marqués, G. G.; Tugores, A.; "Multiple myeloma, severe hypercalcaemia, acute renal failure and multiple organ failure due to calcinosis"; Nefrología, 31, 233-234, 2011.

[51] Merigan, T. C.; Hayes, R. E.; "Treatment of Hypercalcemia in Multiple Myeloma: Report of Two Patients"; Arch. Intern. Med., 107, 389-394, 1961.

[52] David, B.; Tracy, L. N.; Hans-Georg, K.; Benedict, K.; Xiaowei, W.; Jan, R. T.; Craig, J. M.; Johannes, Z.; Jurij, K.; Lawrence, A. K.; "Transitional changes in the CRP structure lead to the exposure of proinflammatory binding sites"; Nat. Commun., 8, 14188, 2017.

[53] Antonio, P.; Avet-Loiseau, H.; Stefania, O.; Henk, M. L.; Hartmut, G.; Laura, R.; Paul, R.; Simona, R.; Juan-José, L.; Thierry, F.; "Revised international staging system for multiple myeloma: a report from International Myeloma Working Group"; J. Clin. Oncol., 33, 2863, 2015.

[54] Sproston, N. R.; Ashworth, J. J.; "Role of C-reactive protein at sites of inflammation and infection"; Front. Immunol., 9, 754, 2018. 